\title{
Safety and efficacy of tocilizumab treatment in children with systemic onset of juvenile idiopathic arthritis
}

\author{
E Alexeeva*, R Denisova, S Valieva, T Bzarova, K Isayeva, T Sleptsova, E Mitenko \\ From 18th Pediatric Rheumatology European Society (PReS) Congress \\ Bruges, Belgium. 14-18 September 2011
}

\section{Objectives}

To evaluate safety and efficacy of tocilizumab treatment in children with systemic onset of juvenile idiopathic arthritis (JIA).

\section{Methods}

A retrospective observational study on JIA patients taking tocilizumab $(n=39)$. Tocilizumab was administered intravenously at a dose of $8 \mathrm{mg} / \mathrm{kg}$ every 2 weeks during 2 months then every 4 weeks. All patients received DMARDs. Efficacy end points included the American College of Rheumatology (ACR) Pediatric 30 (Pedi 30), Pedi 50, Pedi 70, and Pedi 90 criteria for improvement.

\section{Results}

A total of 39 patients ( 21 boys and 18 girls) were included in this Median age was 7,5 years (range; 3 to 15 years) and median disease duration was 4,2 years (range; 0.5 to 8,3 years). A total of 16 of the 39 patients $(25 \%)$ entered 52 weeks of continuous tocilizumab treatment. The frequently observed non-severe adverse events were nasopharyngitis, upper respiratory tract infection and gastroenteritis. No cases of opportunistic infections, malignancies, autoimmune diseases, or death were reported. One case of pneumonia. 21 patients had incidences of neutropenia.The ACR Pedi $30,50,70$ and 90 were achieved by $82 \%, 50 \%, 27 \%$ and $12 \%$ of patients at Week $4(\mathrm{~N}=36)$, and by $100 \%, 81 \%$, $69 \%$, and $50 \%$ of patients at Week $24(\mathrm{~N}=18)$, and by $100 \%, 85 \%, 78 \%$, and $57 \%$ of patients at Week 52 $(\mathrm{N}=16)$, respectively.

* Correspondence: alekatya@yandex.ru

Scientific Center of Children's Health, Moscow, Russian Federation

\section{Conclusion}

Clinical improvements in the signs and symptoms of systemic JIA were also achieved in favorable levels in tocilizumab in the treatment of children with JIA.

Published: 14 September 2011

doi:10.1186/1546-0096-9-S1-P202

Cite this article as: Alexeeva et al:: Safety and efficacy of tocilizumab treatment in children with systemic onset of juvenile idiopathic arthritis. Pediatric Rheumatology 2011 9(Suppl 1):P202.
Submit your next manuscript to BioMed Central and take full advantage of:

- Convenient online submission

- Thorough peer review

- No space constraints or color figure charges

- Immediate publication on acceptance

- Inclusion in PubMed, CAS, Scopus and Google Scholar

- Research which is freely available for redistribution
() Biomed Central

\section{Biomed Central}

(c) 2011 Denisova et al; licensee BioMed Central Ltd. This is an open access article distributed under the terms of the Creative Commons Attribution License (http://creativecommons.org/licenses/by/2.0), which permits unrestricted use, distribution, and reproduction in any medium, provided the original work is properly cited. 